\title{
Response of bioinoculents on growth, yield and fiber quality of cotton under irrigation
}

\author{
${ }^{1}$ D. A. Dhale, ${ }^{2}$ S. N. Chatte and ${ }^{2}$ V. T. Jadhav \\ ${ }^{1}$ Post-graduate Department of Botany, SSVPS's, L.K. Dr.P.R. Ghogrey Science College, \\ Dhule (M.S., India) PIN-424005. E-Mail- datta.dhale@yahoo.com \\ ${ }^{2}$ Department of Plant Pathology, Marathwada Agriculture University, Parbhani-431402.
}

\begin{abstract}
A field experiment was conducted at Marathwada Agriculture University, Parbhani (M.S., India) to study the effect of bioinoculents on cotton. A co-cultured formulation of Azospirillum, Phosphorus solubilizing bacteria (PSB) and Pink coloured facultative methylotrops (PPFM) were used as bioinoculants in cotton var. $\mathrm{PH}-348$. Plant growth parameters (length, fresh and dry weight) of shoot and root, yield parameters (weight of bolls, number of bolls per plants, seed cotton yield) and fiber quality parameters (span length, uniformity ratio, micronair value, tenacity, EIG\%, SFI) were determined. Inoculation of Azospirillum, PSB and PPFMs along with chemical fertilizers resulted in to the significant increase in growth and seed cotton yield parameters of irrigated cotton. The interaction effect due to fertilizer and inoculation were significant on all dates of observations. Surat strain of Azospirillum was proved superior at all fertilizer level. The superiority of Surat strain of Azospirillum + PSB + PPFM was evident at all the fertilizer level and was immediately followed by MAU strain of Azospirillumn + PSB + PPFM. The uses of bioinoculents are beneficial in improving the fiber quality up to some extent.
\end{abstract}

Keywords: Azospirillum bioinoculants' Phosphorus solubilizing bacteria 'Pink Coloured facultative methylotrops.

\section{INTRODUCTION}

Cotton is one of the most important commercial crops in India being a major source of foreign exchange. It is an important raw material for ginning and textile industries. Water and essential nutrients suffice the growth of crops. The latter may be of organic or inorganic in nature. Inorganic fertilizers are costlier and lead to environmental hazards. Exclusive use of organic fertilizers can not meet the nutritional requirements of the crop species [1]. It is there fore, desirable to apply integrated plant nutrient system which involves both the organic as well as inorganic fertilizers. Bioinoculants are significant constituent in integrated plant nutrient system. They are advantageous supplied through biofertigation, being more water and fertilizer use efficient. They are efficiently applied in the filed alongwith organic or inorganic materials [9]. The organic and biological nutrient sources provide essential nutrients to the crop and also enhance the positive interaction with chemical fertilizers [1]. Beneficial bacteria such as Azospirillum, phosphobacteria and methylotrophs coloniz in the rhizosphere region. There fix nitrogen, solubilize phosphorus and stimulate plant growth. Methylobacterium sp. on coinoculation with
Rhizobium sp. TNAU14 show better plant growth, nodulation and yield attributes in case of groundnut, in contract to their individual inoculation [14]. The biofertigation can deliver the bioinoculants precisely in the root zone. However this technology needs more standardization. Literature on this line is still very scarce. The present study was therefore undertaken to evaluate the performance of bioinoculants under field condition for cotton.

\section{MATERIALS AND METHODS}

A micro plot experiment was conducted to examine the response of bioinoculants to growth, yield and fiber quality of cotton cultivar $\mathrm{PH}-348$ under irrigation at Research farm, Department of Agronomy, Marathwada Agriculture University, Parbhani (M.S. India). The experiment was laid out in a split plot design and replicated thrice. The net plot size was 3 $x 3.6 \mathrm{~m}$ with proper irrigation channels. Well decomposed farmyard manure at the rate of 5 tones hectare $^{-1}$ was applied and mixed thoroughly. Similarly, recommended dose of $100 \% \mathrm{~K}_{2} \mathrm{O}$ were applied to main plots. The following treatments were used in this study:

FIELD TRIALS: 


\section{i) Main Plot:}

$\mathrm{M}_{0}-$ Control (zero $\mathrm{N}$ and $\mathrm{P}$ )

$\mathrm{M}_{1}-50 \% \mathrm{~N}$ and $\mathrm{P}$ of the recommended dose

$\mathrm{M}_{2}-75 \% \mathrm{~N}$ and $\mathrm{P}$ of the recommended dose

$\mathrm{M}_{3}-100 \% \mathrm{~N}$ and $\mathrm{P}$ of the recommended dose

ii) Sub Plot

$\mathrm{S}_{1}-$ Azospirillum TNAU + PSB + PPFM

$\mathrm{S}_{2}-$ Azospirillum MAU + PSB + PPFM

$\mathrm{S}_{3}-$ Azospirillum Surat strain + PSB + PPFM

$\mathrm{S}_{4}-$ Control (no bioinoculant)

iii) Treatment Combinations

$\begin{array}{llll}M_{0} S_{1} & M_{0} S_{2} & M_{0} S_{3} & M_{0} S_{4}\end{array}$

$\begin{array}{llll}M_{1} S_{1} & M_{1} S_{2} & M_{1} S_{3} & M_{1} S_{4}\end{array}$

$\begin{array}{llll}M_{2} S_{1} & M_{2} S_{2} & M_{2} S_{3} & M_{2} S_{4}\end{array}$

$\begin{array}{llll}M_{3} S_{1} & M_{3} S_{2} & M_{3} S_{3} & M_{3} S_{4}\end{array}$

Bioinoculats: The Azospirillum strain from Surat, one available in our department was tested alongwith effective microorganism (EM) cultures and another obtained from Department of Agricultural Chemistry and Soil Sciences (ACSS), Marathwada Agriculture University (MAU), Parbhani (M.S., India). The bacterial suspension having a count of $10^{7}$ c.f.u. $\mathrm{ml}^{-1}$ was added at the time of sowing just over the seed @ $2 \mathrm{ml} \mathrm{hill}^{-1}$.

The PSB strain from TNAU, Coimbatore and one available in our department was tested alongwith effective microorganism (EM) cultures, collected from Department of ACSS, Marathwada Agriculture University, Parbhani (M.S.). The bacterial suspension having a count of $10^{7}$ c.f.u. $\mathrm{ml}^{-1}$ was added at the time of sowing just over the seed @ $2 \mathrm{ml} \mathrm{hill}^{-1}$.

The PPFM strain from TNAU, Coimbatore and another available in our department was tested alongwith effective microorganism (EM) cultures, collected from Department of ACSS, Marathwada Agriculture University, Parbhani (M.S.). The bacterial suspension having a count of $10^{7}$ c.f.u. $\mathrm{ml}^{-1}$ was added at the time of sowing just over the seed @ $2 \mathrm{ml}$ hill ${ }^{-1}$.

Treatment of seeds: Three most efficient Azospirillium strains were used for inoculation of seeds. A strain of phosphobacteria isolated and found most effective, was used for inoculation alongwith Azospirillium strains and plant growth promoters producing organisms like pink coloured facultative methylotrophs (PPFMs). The bacterial suspension having a count of $10^{7}$ (c.f.u. $\mathrm{ml}^{-1}$ ) was added at the time of sowing, just over the seed on each hill @2ml hill ${ }^{-1}$. Apart from these treatments, the PPFM was also applied as phyllosphere spray on $45^{\text {th }}$ and $90^{\text {th }}$ day of crop age.
Sowing was done by dibbing at row to row $60 \mathrm{~cm}$ and plant to plant $30 \mathrm{~cm}$ spacing by placing to seeds at each hill. After germination, one plant per hill was maintained. Irrigation was given as per requirement of crop. Standard plant protection schedule was followed to protect the crop from diseases and pests.

Preparation of Standard Inoculum: The standard inoculums was prepared by inoculating log phase cultures of bioinoculants viz., Azospirillum in N-free malic acid broth, PSB in pikovskya's broth and PPFM in Ammonical mineral salt (AMS) broth.

The observations on different growth parameters were recorded after 45, 90 and 135 days of sowing (DAS). The length of shoot was adjusted by taking the physical count of the length of the shoot from color region to apical bud. Length of root was adjudged by taking the physical count of the length of root from color region to the tip of tap root. The fresh root and shoot samples were measured physically on top loading balance. The resulting weights were recorded as shoot and root fresh weight in gram. The dry matter accumulation by root and shoot was recorded by subjecting the roots and shoots to oven drying at $60^{\circ} \mathrm{C}$ till the constant weight and physical weight was recorded.

Five plants were sampled for recording the boll weight on 90 DAS. Five bolls were selected randomly each from top, middle and lower portion of cotton plant. These bolls were picked up and weighted on physical balance and the average weight so obtained was recorded as weight of bolls. While for boll number, total numbers of bolls on each plant were counted physically and average numbers of bolls were recorded as number of bolls. The representative sample of around $110 \mathrm{~g}$ of cotton lint each from all treatments and replications were drawn and sent to CICR laboratory, Athwa farm, Surat (India) and data on fiber quality parameters was drawn.

The data on growth parameter and cotton seed yield was subjected to statistical significance given Panse and Sukhatme (1967). The critical differences at 5 percent level were reported, whenever necessary, for interpretation.

\section{RESULTS AND DISCUSSION}

Plant Growth Parameters: The effect of combined inoculation of bioinoculants on plant height and root length of cotton was studied and data are presented in Table 1. The data clearly indicated that shoot and root length of cotton was significantly increased with the application of chemical fertilizers on all the dates 
of observation. Maximum shoot and root length was observed in the plot receiving recommended dose of fertilizer and it was 43.58, 86.16 and $127.16 \mathrm{~cm}$ in shoot and $17.03,35.58$ and $37.66 \mathrm{~cm}$ in root on 45 , 90 and 135 DAS respectively. Minimum of them were observed in the plots without fertilizers. With regard to the effect of the inoculation the data (Table 1) clearly indicated that combined inoculation of bioinoculants of Azospirillum, PSB and PPFM brought about the significant increment in shoot and root length as compared to uninoculated control on all the dates of observation. Amongst the different strains, Surat strain Azospirillum + PSB + PPFM brought about maximum increment in shoot $(42.25$, 85.75 and $120.50 \mathrm{~cm})$ and root $(18.08,34.91$ and $36.91 \mathrm{~cm})$ on 45,90 and 135 DAS respectively. It was followed by the MAU strains of Azospirillum with other inoculants. The interaction effects due to fertilizer application and microbial inoculation were significant on all the dates of observation. The data presented (Table 2) apparently indicated that microbial inoculations brought significant increment in shoot length as recorded on 45, 90 and 135 DAS. The beneficial influences due to Azospirillum, PSB and PPFM were evident even with the increased doses of fertilizer application. Surat strain of Azospirillum has proved to be better at all the fertilizer levels followed by MAU strain of Azospirillum + PSB + PPFM. Such beneficial effect due to inoculation of $\mathrm{N}$-fixers and $\mathrm{P}$ solubilizer has been reported in the past. Increase the plant height in sorghum with the application of Azospirillum [16]. Similar hearsay has been reported in different crop plants $[5,13,20,23,33]$. Beneficial effect due to inoculation of $\mathrm{N}$-fixers and $\mathrm{P}$ solubilizer with PPFM has also been reported $[3,10]$.

The interaction effect due to fertilizer application and microbial inoculation on plant fresh and dry shoot weight of cotton was studied. The data (Table 3) obviously indicated that fresh shoot weight was increased significantly on 45 and 135 DAS and nonsignificantly on 90 DAS, with the increased application of chemical fertilizers. The trend was similar on all the dates of observation. Maximum fresh shoot weight was obtained in the plot receiving recommended dose of fertilizer and it was 58.16, 297.08 and $431.58 \mathrm{~g}$ on 45, 90 and 135 DAS respectively. The weight of dry shoot was increased with the increased application of chemical fertilizers. The maximum dry shoot weight was obtained in the plot receiving $100 \%$ recommended dose of fertilizers and it was $9.91,89.16$ and $144.25 \mathrm{~g}$ on observation day. It is statistically and comparatively more than the other treatments. With regard to the combined inoculation of Azospirillum, PSB and PPFM, significant increase in fresh shoot weight was observed on 45 and 90 DAS. Strain of Azospirillum + PSB + PPFM brought about significant in fresh shoot weight as compared to other strains. It was 55.58, 310.92 and $410.67 \mathrm{~g}$ on 45,90 and $135 \mathrm{DAS}$ respectively. The Surat strain of Azospirillum + PSB + PPFM has brought about significantly more dry shoot weight. It was $9.91,95.91$ and $146.75 \mathrm{~g}$ on study day respectively. The interaction effects due to fertilizer application and inoculation were significant and the relevant data are existing in Table 4. The data apparently indicated that the beneficial influence of inoculations were evident in all the fertilizer levels. The superiority of Surat strain of Azospirillum + PSB + PPFM in fresh and dry shoot weight accumulation over other strains was observed at all the fertilizer level and all the dates of observation. The result obtained in the present investigation is in agreement with those reported in the past. Significant increase in shoot biomass accumulation of peal millet plant when inoculated with Azospirillum lipoferum [28]. The inoculation of Azospirillum obtained the more plant biomass in sorghum [16]. Similar results have been reported in different cultivated crops $[2,6,7,10,12$, $26,27,32]$. 
Agric. Biol. J. N. Am., 2011, 2(2): 376-386

Table 1: Effect of bioinoculants on plant height $(\mathrm{cm})$ of irrigated cotton at different fertilizer level.

\begin{tabular}{|l|c|c|c|c|c|c|}
\hline \multirow{2}{*}{ Treatment } & \multicolumn{3}{|c|}{ Shoot length (cm) } & \multicolumn{3}{c|}{ Root length (cm) } \\
\cline { 2 - 7 } & 45 DAS & 90 DAS & 135 DAS & 45 DAS & 90 DAS & 135 DAS \\
\hline Main Plot & & & & & & \\
No N, P \& K at RDF & 38.00 & 76.88 & 106.17 & 16.33 & 29.83 & 30.58 \\
50\% N, P \& K at RDF & 39.41 & 77.66 & 111.25 & 16.75 & 30.41 & 33.33 \\
$75 \%$ N, P \& K at RDF & 39.70 & 81.66 & 113.75 & 16.75 & 3325 & 34.16 \\
100\% N, P \& K at RDF & 43.58 & 86.16 & 127.17 & 17.03 & 35.58 & 37.66 \\
SE & 1.34 & 1.37 & 4.18 & 0.59 & 1.25 & 0.98 \\
CD at 5\% & NS & 4.01 & NS & NS & NS & 2.85 \\
Sub plot & & & & & & \\
TNAU AZO + PSB + PPFB & 39.33 & 79.75 & 110.50 & 16.41 & 30.25 & 32.16 \\
MAU AZO + PSB + PPFM & 40.35 & 81.33 & 117.50 & 16.91 & 33.83 & 33.91 \\
Surat AZO + PSB + PPFM & 42.25 & 85.75 & 120.50 & 18.08 & 34.91 & 36.91 \\
No inoculation & 38.66 & 75.50 & 109.83 & 15.00 & 30.08 & 30.75 \\
SE & 0.60 & 1.09 & 4.16 & 0.59 & 1.06 & 1.06 \\
CD at 5\% & 1.75 & 3.19 & NS & 1.72 & 3.10 & 3.10 \\
Interaction (Fertilizer x inoculation) & & & & & & \\
SE & 1.20 & 2.19 & 8.33 & 1.18 & 2.13 & 2.13 \\
CD at 5\% & 3.50 & 6.38 & 24.27 & NS & 6.21 & 6.21 \\
\hline
\end{tabular}

$\mathrm{SE}=$ Standard error, $\mathrm{CD}=$ Critical difference, $\mathrm{NS}=$ Non-significant, $\mathrm{RDF}=$ Recommended dose of fertilizers, $\mathrm{DAS}=$ Days after sowing

Table 2: Interaction effect fertilizer and inoculation on plant height of irrigated cotton

\begin{tabular}{|c|c|c|c|c|c|c|}
\hline \multirow[t]{2}{*}{ Treatment } & \multicolumn{3}{|c|}{ Shoot length (cm) } & \multicolumn{3}{|c|}{ Root length $(\mathrm{cm})$} \\
\hline & 45 DAS & 90 DAS & 135 DAS & 45 DAS & $90 \mathrm{DAS}$ & 135 DAS \\
\hline $\mathrm{M}_{0} \mathrm{~S}_{1}$ & 38.66 & 73.33 & 108.67 & 16.00 & 38.00 & 33.00 \\
\hline $\mathrm{M}_{0} \mathrm{~S}_{2}$ & 40.66 & 78.33 & 118.33 & 16.66 & 38.66 & 38.00 \\
\hline $\mathrm{M}_{0} \mathrm{~S}_{3}$ & 41.00 & 90.00 & 121.33 & 1933 & 40.00 & 48.33 \\
\hline $\mathrm{M}_{0} \mathrm{~S}_{4}$ & 37.33 & 69.00 & 106.67 & 15.00 & 25.66 & 31.33 \\
\hline$M_{1} S_{1}$ & 37.66 & 80.33 & 123.00 & 16.00 & 30.33 & 32.33 \\
\hline $\mathrm{M}_{1} \mathrm{~S}_{2}$ & 39.00 & 80.66 & 129.33 & 16.66 & 32.33 & 36.00 \\
\hline $\mathrm{M}_{1} \mathrm{~S}_{3}$ & 40.33 & 86.33 & 135.33 & 18.00 & 34.00 & 37.66 \\
\hline $\mathrm{M}_{1} \mathrm{~S}_{4}$ & 35.00 & 79.33 & 121.00 & 14.66 & 25.00 & 27.33 \\
\hline $\mathrm{M}_{2} \mathrm{~S}_{1}$ & 43.00 & 88.00 & 97.00 & 18.00 & 30.00 & 31.33 \\
\hline $\mathrm{M}_{2} \mathrm{~S}_{2}$ & 44.33 & 90.00 & 107.33 & 18.33 & 30.00 & 34.33 \\
\hline $\mathrm{M}_{2} \mathrm{~S}_{3}$ & 45.00 & 91.33 & 128.33 & 18.33 & 47.00 & 35.33 \\
\hline $\mathrm{M}_{2} \mathrm{~S}_{4}$ & 42.00 & 75.33 & 92.00 & 13.66 & 26.00 & 27.66 \\
\hline$M_{3} S_{1}$ & 39.66 & 77.33 & 102.33 & 15.66 & 29.66 & 38.00 \\
\hline $\mathrm{M}_{3} \mathrm{~S}_{2}$ & 41.33 & 85.66 & 107.00 & 16.66 & 31.33 & 32.00 \\
\hline $\mathrm{M}_{3} \mathrm{~S}_{3}$ & 44.66 & 86.67 & 135.67 & 19.33 & 33.00 & 35.00 \\
\hline $\begin{array}{l}M_{3} S_{4} \\
\text { Main } \times \text { Sub }\end{array}$ & 33.33 & 75.66 & 100.00 & 15.33 & 25.33 & 27.33 \\
\hline & 1.20 & 2.19 & 8.33 & 1.18 & 2.013 & 2.13 \\
\hline CD at $5 \%$ & 3.50 & 6.38 & 24.20 & 3.45 & 6.21 & 6.21 \\
\hline
\end{tabular}

$\mathrm{SE}=$ Standard error, $\mathrm{CD}=$ Critical difference, $\mathrm{DAS}=$ Days after sowing 
Agric. Biol. J. N. Am., 2011, 2(2): 376-386

Table 3: Effect of bioinoculants on shoot weight $(\mathrm{g})$ of irrigated cotton at different fertilizer level.

\begin{tabular}{|c|c|c|c|c|c|c|}
\hline \multirow[t]{2}{*}{ Treatment } & \multicolumn{3}{|c|}{ Fresh shoot weight (g) } & \multicolumn{3}{|c|}{ Dry shoot weight (g) } \\
\hline & 45 DAS & 90 DAS & 135 DAS & 45 DAS & 90 DAS & 135 DAS \\
\hline \multicolumn{7}{|l|}{ Main Plot } \\
\hline No N, P \& $K$ at RDF & 46.58 & 254.92 & 313.83 & 7.66 & 73.58 & 110.75 \\
\hline $50 \% \mathrm{~N}, \mathrm{P} \& \mathrm{~K}$ at RDF & 47.33 & 259.58 & 370.25 & 8.5 & 80.25 & 136.42 \\
\hline $75 \% \mathrm{~N}, \mathrm{P} \& \mathrm{~K}$ at RDF & 55.25 & 277.42 & 423.67 & 9.57 & 84.08 & 137.17 \\
\hline $100 \% \mathrm{~N}, \mathrm{P} \& \mathrm{~K}$ at RDF & 58.16 & 297.08 & 431.58 & 9.91 & 89.16 & 144.25 \\
\hline SE & 0.90 & 12.35 & 16.74 & 0.47 & 3.11 & 6.16 \\
\hline CD at $5 \%$ & 2.62 & NS & 48.74 & NS & NS & 17.96 \\
\hline \multicolumn{7}{|l|}{ Sub plot } \\
\hline TNAU் AZO + PSB + PPFB & 49.66 & 246.42 & 373.17 & 8.33 & 76.00 & 122.17 \\
\hline MAU AZO + PSB + PPFM & 53.75 & 303.08 & 397.42 & 9016 & 89.66 & 139.67 \\
\hline Surat AZO + PSB + PPFM & 55.58 & 310.92 & 410.67 & 9.91 & 95.91 & 146.75 \\
\hline No inoculation & 48.33 & 228.58 & 358.08 & 8.24 & 65.00 & 120.00 \\
\hline SE & 0.96 & 9.81 & 14.57 & 0.49 & 3.24 & 4.09 \\
\hline CD at $5 \%$ & 2.80 & 28.60 & NS & NS & 9.45 & 11.92 \\
\hline \multicolumn{7}{|c|}{ Interaction (Fertilizer $\mathrm{x}$ inoculation) } \\
\hline \multicolumn{7}{|l|}{ SE } \\
\hline \multirow[t]{2}{*}{$\mathrm{CD}$ at $5 \%$} & 1.92 & 19.62 & 29.14 & 0.99 & 6.48 & 8.18 \\
\hline & 5.61 & 57.19 & 84.94 & NS & 18.90 & 23.85 \\
\hline
\end{tabular}

$\mathrm{SE}=$ Standard error, $\mathrm{CD}=$ Critical difference, NS $=$ Non-significant, RDF= Recommended dose of fertilizers, DAS $=$ Days after sowing

Table 4: Interaction effect fertilizer and inoculation on shoot weight $(\mathrm{g})$ of irrigated cotton.

\begin{tabular}{|c|c|c|c|c|c|c|}
\hline \multirow[t]{2}{*}{ Treatment } & \multicolumn{3}{|c|}{ Fresh shoot weight (g) } & \multicolumn{3}{|c|}{ Dry shoot weight (g) } \\
\hline & 45 DAS & 90 DAS & 135 DAS & 45 DAS & 90 DAS & 135 DAS \\
\hline $\mathrm{M}_{0} \mathrm{~S}_{1}$ & 52.33 & 261.33 & 336.00 & 9.00 & 69.33 & 114.67 \\
\hline $\mathrm{M}_{0} \mathrm{~S}_{2}$ & 55.33 & 315.33 & 405.33 & 9.66 & 98.66 & 131.67 \\
\hline $\mathrm{M}_{0} \mathrm{~S}_{3}$ & 65.33 & 328.67 & 717.67 & 11.33 & 103.67 & 239.33 \\
\hline $\mathrm{M}_{0} \mathrm{~S}_{4}$ & 48.00 & 204.33 & 267.33 & 8.33 & 64.66 & 91.33 \\
\hline$M_{1} S_{1}$ & 41.66 & 216.33 & 318.67 & 8.33 & 58.33 & 108.33 \\
\hline$M_{1} S_{2}$ & 44.66 & 243.67 & 506.00 & 8.33 & 65.00 & 156.67 \\
\hline $\mathrm{M}_{1} \mathrm{~S}_{3}$ & 59.66 & 372.67 & 565.33 & 9.66 & 117.33 & 180.00 \\
\hline $\mathrm{M}_{1} \mathrm{~S}_{4}$ & 40.33 & 187.00 & 304.67 & 7.66 & 53.66 & 100.00 \\
\hline $\mathrm{M}_{2} \mathrm{~S}_{1}$ & 52.66 & 290.33 & 299.33 & 8.66 & 85.33 & 109.80 \\
\hline $\mathrm{M}_{2} \mathrm{~S}_{2}$ & 60.66 & 323.67 & 310.00 & 11.00 & 94.33 & 118.00 \\
\hline $\mathrm{M}_{2} \mathrm{~S}_{3}$ & 70.66 & 328.00 & 394.00 & 11.66 & 105.67 & 129.33 \\
\hline $\mathrm{M}_{2} \mathrm{~S}_{4}$ & 48.66 & 246.33 & 252.00 & 8.33 & 71.33 & 86.66 \\
\hline $\mathrm{M}_{3} \mathrm{~S}_{1}$ & 44.33 & 220.00 & 354.33 & 7.00 & 67.66 & 138.61 \\
\hline $\mathrm{M}_{3} \mathrm{~S}_{2}$ & 48.66 & 65.33 & 423.00 & 8.33 & 82.33 & 152.67 \\
\hline $\mathrm{M}_{3} \mathrm{~S}_{3}$ & 52.33 & 368.67 & 447.00 & 8.33 & 107.00 & 169.33 \\
\hline $\mathrm{M}_{3} \mathrm{~S}_{4}$ & 44.00 & 184.33 & 256.00 & 7.00 & 64.00 & 88.00 \\
\hline Main x Sub & & & & & & \\
\hline SE & 1.92 & 19.62 & 29.14 & 0.99 & 6.48 & 8.18 \\
\hline CD at $5 \%$ & 5.61 & 57.19 & 84.94 & 2.90 & 18.90 & 23.85 \\
\hline
\end{tabular}

$\mathrm{SE}=$ Standard error, $\mathrm{CD}=$ Critical difference, $\mathrm{DAS}=$ Days after sowing

recommended dose of fertilizer and it was 4.33,

The interaction effect due to fertilizer application and microbial inoculation on plant fresh and dry root weight of cotton was studied. The data are available in Table 5. The figures evidently indicated that fresh root weight was increased, with the increased application of chemical fertilizers. The trend was similar on all the dates of observation. Maximum fresh root weight was obtained in the plot receiving 23.58 and $25.33 \mathrm{~g}$ on 45,90 and 135 DAS respectively. The weight of dry root was increased, significantly on 45 and 90 DAS and non significantly on 135 DAS, with the increased application of chemical fertilizers. Maximum dry root weight was observed in the plot receiving recommended dose of fertilizers and it was 1.02, 9.66 and $9.75 \mathrm{~g}$ on remarks day respectively. With regard to the 
inoculation of Surat strain of Azospirillum + PSB + PPFM has brought about significant increment in fresh and dry root weight and it was 4.16, 22.58 and $22.66 \mathrm{~g}$ and $0.90,8.16$ and 9.33 on 45,90 and 135 DAS respectively. It was followed by MAU strain of Azospirillum + PSB + PPFM. The interaction effects due to fertilizer application and inoculation were significant and the relevant data are presented in Table 6 . The data, in fact, indicated the influence of bioinoculants at all the fertilizer regimes. The increased levels of chemical fertilizer seem to have no effect on the bacterial activity. The superiority of Surat strain of Azospirillum + PSB + PPFM on fresh and dry root weight accumulation over other strains was observed at all the fertilizer levels and all the dates of observations. It was immediately followed by MAU strain of Azospirillum + PSB + PPFM inoculation. The increase in root biomass of cotton obtained in the present investigation is in full concurrence with those reported in the past; especially increased growth of root in pearl millet with Azospirillum inoculation [29]. Similar results have been reported in different crop plants $[6,10,11,18$, $22,27,32,33]$.

The outcome of inoculation of bioinoculants on boll weight and ball number of cotton was studied on 90 DAS and data are presented in Table 7 . The data definitely indicated that the weight and number of bolls was significantly improved with the application of chemical fertilizers. The plot receiving recommended dose of fertilizer show maximum boll weight (29.83g) and number of boll per plant (8.20).
This was significantly more than the boll weights and number of bolls recorded in other treatments. With regard to inoculations, plot inoculated with Surat strain of Azospirillum + PSB + PPFM recorded greatest boll weight $(32.33 \mathrm{~g})$ and up most boll number (8.96) followed by MAU strain of Azospirillum + PSB + PPFM. Significantly lower boll weight (26.41g) and boll per plant was recorded in the plot receiving no bioinoculants. The interaction effects due to fertilizer application and inoculation for number of bolls were considerable. The data (Table 8) clearly indicated that the increased levels of fertilizer have increased the weight and number of bolls in cotton. The inoculations have brought about the significant increase in weight and number of bolls at all the fertilizer levels. It was always the Surat strain of Azospirillum + PSB + PPFM, which performed well at all fertilizer levels. It was followed by MAU strain of Azospirillum + PSB + PPFM inoculation. The beneficial effects on the growth of the plant obtained in the present search are in full concord with those reported in the past. Increase in grain dry matter and yield of some pearl millet cultivars when inoculated with Azospirillum lipoferum and Azospirillum brasilense [34]. The increase in biomass production of gram was observed when inoculated with different phosphate solubilizers [30] and obtained more number of pods per plant when soyabean was treated with PSB in combination with Rhizobium [13]. Similar results have been reported in various cultivated plants $[6,10,15,23,27]$. 
Agric. Biol. J. N. Am., 2011, 2(2): 376-386

Table 5: Effect of bioinoculants on root weight $(\mathrm{g})$ of irrigated cotton at different fertilizer level.

\begin{tabular}{|c|c|c|c|c|c|c|}
\hline \multirow[t]{2}{*}{ Treatment } & \multicolumn{3}{|c|}{ Fresh root weight (g) } & \multicolumn{3}{|c|}{ Dry root weight $(g)$} \\
\hline & 45 DAS & 90 DAS & 135 DAS & 45 DAS & 90 DAS & 135 DAS \\
\hline \multicolumn{7}{|l|}{ Main Plot } \\
\hline No N, P \& $K$ at RDF & 3.41 & 15.33 & 17.16 & 0.68 & 6.25 & 7.25 \\
\hline $50 \% \mathrm{~N}, \mathrm{P} \& \mathrm{~K}$ at RDF & 3.58 & 1950 & 18.33 & 0.76 & 6.75 & 7.91 \\
\hline $75 \% \mathrm{~N}, \mathrm{P} \& \mathrm{~K}$ at RDF & 3.91 & 2016 & 21.16 & 9.92 & 7.33 & 8.50 \\
\hline $100 \% \mathrm{~N}, \mathrm{P} \& \mathrm{~K}$ at RDF & 4.33 & 23.58 & 25.33 & 1.02 & 9.66 & 9.75 \\
\hline SE & 0.26 & 1.17 & 0.75 & 0.015 & 0.24 & 0.64 \\
\hline CD at $5 \%$ & NS & 3.43 & NS & 0.045 & 0.72 & NS \\
\hline \multicolumn{7}{|l|}{ Sub plot } \\
\hline TNAU AZO + PSB + PPFB & 3.83 & 19.83 & 20.41 & 0.87 & 7.58 & 8.91 \\
\hline MAU AZO + PSB + PPFM & 3.83 & 21.00 & 21.33 & 0.87 & 7.75 & 8.91 \\
\hline Surat AZO + PSB + PPFM & 4.16 & 22.58 & 22.66 & 0.90 & 8.16 & 9.33 \\
\hline No inoculation & 3.41 & 15.16 & 17.58 & 0.73 & 6.50 & 6.25 \\
\hline SE & 0.25 & 0.80 & 0.75 & 0.018 & 0.38 & 0.40 \\
\hline CD at $5 \%$ & NS & 2.35 & 2.18 & 0.052 & 1.11 & 1.18 \\
\hline \multicolumn{7}{|c|}{ Interaction (Fertilizer $\mathrm{x}$ inoculation) } \\
\hline \multirow{3}{*}{$\begin{array}{l}\mathrm{SE} \\
\mathrm{CD} \text { at } 5 \%\end{array}$} & & & & & & \\
\hline & 0.50 & 1.61 & 1.50 & 0.036 & 0.76 & 0.81 \\
\hline & NS & 4.71 & 4.37 & 0.10 & 2.23 & 2.36 \\
\hline
\end{tabular}

SE= Standard error, $C D=$ Critical difference, NS= Non-significant, RDF= Recommended dose of fertilizers, DAS= Days after sowing

Table 6: Interaction effect fertilizer and inoculation on root weight of irrigated cotton.

\begin{tabular}{|c|c|c|c|c|c|c|}
\hline \multirow{2}{*}{ Treatment } & \multicolumn{3}{|c|}{ Fresh root weight (g) } & \multicolumn{3}{|c|}{ Dry root weight (g) } \\
\hline & 45 DAS & 90 DAS & $135 \mathrm{DAS}$ & 45 DAS & 90 DAS & $135 \mathrm{DAS}$ \\
\hline $\mathrm{M}_{0} \mathrm{~S}_{1}$ & 4.00 & 20.33 & 22.00 & 0.78 & 7.66 & 8.66 \\
\hline $\mathrm{M}_{0} \mathrm{~S}_{2}$ & 4.00 & 22.00 & 28.66 & 0.80 & 9.66 & 9.0 \\
\hline $\mathrm{M}_{0} \mathrm{~S}_{3}$ & 4.66 & 30.66 & 35.00 & 1.15 & 15.33 & 13.66 \\
\hline $\mathrm{M}_{0} \mathrm{~S}_{4}$ & 3.00 & 17.33 & 15.66 & 0.65 & 6.00 & 7.66 \\
\hline $\mathrm{M}_{1} \mathrm{~S}_{1}$ & 3.33 & 18.66 & 13.66 & 0.67 & 5.33 & 7.66 \\
\hline $\mathrm{M}_{1} \mathrm{~S}_{2}$ & 3.33 & 22.33 & 20.66 & 0.72 & 6.66 & 8.33 \\
\hline $\mathrm{M}_{1} \mathrm{~S}_{3}$ & 3.66 & 24.33 & 22.66 & 0.77 & 8.33 & 9.33 \\
\hline $\mathrm{M}_{1} \mathrm{~S}_{4}$ & 3.33 & 15.13 & 21.66 & 0.59 & 4.66 & 6.33 \\
\hline $\mathrm{M}_{2} \mathrm{~S}_{1}$ & 4.33 & 12.33 & 20.00 & 0.98 & 7.33 & 4.66 \\
\hline $\mathrm{M}_{2} \mathrm{~S}_{2}$ & 4.66 & 18.33 & 21.66 & 1.01 & 7.33 & 9.00 \\
\hline $\mathrm{M}_{2} \mathrm{~S}_{3}$ & 5.00 & 18.67 & 24.33 & 1.19 & 8.00 & 11.33 \\
\hline $\mathrm{M}_{2} \mathrm{~S}_{4}$ & 3.33 & 12.00 & 18.66 & 0.90 & 6.66 & 4.00 \\
\hline $\mathrm{M}_{3} \mathrm{~S}_{1}$ & 3.66 & 19.00 & 15.33 & 0.74 & 5.33 & 8.33 \\
\hline $\mathrm{M}_{3} \mathrm{~S}_{2}$ & 3.66 & 21.33 & 27.00 & 0.76 & 8.33 & 10.00 \\
\hline $\mathrm{M}_{3} \mathrm{~S}_{3}$ & 4.00 & 25.33 & 26.00 & 0.83 & 8.66 & 10.33 \\
\hline $\mathrm{M}_{3} \mathrm{~S}_{4}$ & 3.00 & 12.66 & 15.00 & 0.70 & 4.66 & 5.33 \\
\hline Main x Sub & & & & & & \\
\hline SE & 0.50 & 1.61 & 1.50 & 0.03 & 0.76 & 0.81 . \\
\hline CD at $5 \%$ & 1.47 & 4.71 & 4.37 & 0.70 & 2.23 & 2.36 \\
\hline
\end{tabular}

$\mathrm{SE}=$ Standard error, $\mathrm{CD}=$ Critical difference, $\mathrm{DAS}=$ Days after sowing 
Agric. Biol. J. N. Am., 2011, 2(2): 376-386

Table 7: Effect of bioinoculants on plant height $(\mathrm{cm})$ on irrigated cotton at different fertilizer level.

\begin{tabular}{|c|c|c|c|c|c|}
\hline \multirow{2}{*}{ Treatment } & \multirow{2}{*}{$\begin{array}{l}\text { Weight of } \\
\text { bolls }(\mathrm{g})\end{array}$} & \multirow{2}{*}{$\begin{array}{c}\text { No. of } \\
\text { boll/plant }\end{array}$} & \multicolumn{3}{|c|}{ Seed cotton yield } \\
\hline & & & G/ plant & $\mathrm{Kg} / \mathrm{plot}$ & $\mathrm{Kg} / \mathrm{ha}$ \\
\hline \multicolumn{6}{|l|}{ Main Plot } \\
\hline No $N, P \& K$ at RDF & 25.16 & 7.56 & 14.56 & 0.874 & 2023.15 \\
\hline $50 \% \mathrm{~N}, \mathrm{P} \& \mathrm{~K}$ at RDF & 25.16 & 7.58 & 15.33 & 0.908 & 2101.85 \\
\hline $75 \% \mathrm{~N}, \mathrm{P} \& \mathrm{~K}$ at RDF & 29.50 & 8.09 & 16.29 & 0.978 & 2263.90 \\
\hline $100 \% \mathrm{~N}, \mathrm{P} \& \mathrm{~K}$ at RDF & 29.83 & 8.20 & 16.81 & 1.009 & 2335.65 \\
\hline SE & 0.64 & 0.15 & 0.29 & 0.018 & 41.67 \\
\hline $\mathrm{CD}$ at $5 \%$ & 1.88 & 0.45 & 0.88 & 0.053 & 122.67 \\
\hline \multicolumn{6}{|l|}{ Sub plot } \\
\hline TNAU AZO + PSB + PPFB & 26.41 & 7.59 & 15.24 & 0.915 & 2108.80 \\
\hline MAU AZO + PSB + PPFM & 29.00 & 8.12 & 15.89 & 0.954 & 2118.07 \\
\hline Surat AZO + PSB + PPFM & 32.33 & 8.96 & 16.48 & 0.989 & 2289.35 \\
\hline No inoculation & 21.91 & 6.76 & 15.18 & 0.911 & 2083.35 \\
\hline SE & 0.76 & 0.11 & 0.36 & 0.022 & 50.92 \\
\hline CD at $5 \%$ & 2.22 & 0.33 & NS & NS & NS \\
\hline \multicolumn{6}{|c|}{ Interaction (Fertilizer $x$ inoculation) } \\
\hline \multirow{3}{*}{$\begin{array}{l}\text { SE } \\
\text { CD at } 5 \%\end{array}$} & & & & & \\
\hline & 1.52 & 0.22 & 0.75 & 0.045 & 41.67 \\
\hline & 4.45 & 0.66 & 2.21 & 0.133 & 132.15 \\
\hline
\end{tabular}

$\mathrm{SE}=$ Standard error, $\mathrm{CD}=$ Critical difference, $\mathrm{NS}=$ Non-significant, RDF= Recommended dose of fertilizers

Table 8: Interaction effect fertilizer and inoculation on yield parameter of irrigated cotton.

\begin{tabular}{|c|c|c|c|c|c|}
\hline \multirow{2}{*}{ Treatment } & \multirow{2}{*}{$\begin{array}{l}\text { Weight of bolls } \\
\text { (g) }\end{array}$} & \multirow{2}{*}{$\begin{array}{c}\text { No. of } \\
\text { boll/plant }\end{array}$} & \multicolumn{3}{|c|}{ Seed cotton yield } \\
\hline & & & G/ plant & $\mathrm{Kg} / \mathrm{plot}$ & $\mathrm{Kg} / \mathrm{ha}$ \\
\hline $\mathrm{M}_{0} \mathrm{~S}_{1}$ & 7.21 & 24.33 & 14.19 & 0.852 & 1972.22 \\
\hline $\mathrm{M}_{0} \mathrm{~S}_{2}$ & 8.23 & 27.33 & 15.36 & 0.922 & 2134.27 \\
\hline $\mathrm{M}_{0} \mathrm{~S}_{3}$ & 8.31 & 29.00 & 15.71 & 0.943 & 2182.87 \\
\hline $\mathrm{M}_{0} \mathrm{~S}_{4}$ & 6.58 & 20.00 & 12.94 & 0.777 & 1798.62 \\
\hline$M_{1} S_{1}$ & 7.30 & 23.66 & 13.99 & 0.840 & 1944.78 \\
\hline $\mathrm{M}_{1} \mathrm{~S}_{2}$ & 7.55 & 26.00 & 15.44 & 0.927 & 2145.85 \\
\hline $\mathrm{M}_{1} \mathrm{~S}_{3}$ & 8.99 & 31.00 & 18.76 & 1.126 & 2606.60 \\
\hline $\mathrm{M}_{1} \mathrm{~S}_{4}$ & 6.42 & 20.00 & 12.34 & 0.741 & 1751.27 \\
\hline $\mathrm{M}_{2} \mathrm{~S}_{1}$ & 8.16 & 32.00 & 16.16 & 0.970 & 2245.37 \\
\hline $\mathrm{M}_{2} \mathrm{~S}_{2}$ & 8.29 & 33.00 & 17.74 & 1.065 & 2465.12 \\
\hline $\mathrm{M}_{2} \mathrm{~S}_{3}$ & 9.24 & 34.00 & 18.42 & 1.106 & 2560.20 \\
\hline $\mathrm{M}_{2} \mathrm{~S}_{4}$ & 6.68 & 23.33 & 14.42 & 0.896 & 2074.75 \\
\hline $\mathrm{M}_{3} \mathrm{~S}_{1}$ & 7.57 & 27.26 & 14.81 & 0.889 & 2057.87 \\
\hline $\mathrm{M}_{3} \mathrm{~S}_{2}$ & 8.56 & 30.66 & 16.96 & 1.018 & 2356.50 \\
\hline $\mathrm{M}_{3} \mathrm{~S}_{3}$ & 9.29 & 35.33 & 18.19 & 1.116 & 2583.35 \\
\hline $\mathrm{M}_{3} \mathrm{~S}_{4}$ & 7.39 & 24.33 & 14.81 & 0.889 & 2057.87 \\
\hline \multicolumn{6}{|l|}{ Main $x$ Sub } \\
\hline SE & 0.22 & 1.52 & 0.76 & 0.045 & 41.67 \\
\hline CD at $5 \%$ & 0.66 & 4.45 & 2.22 & 0.133 & 123.15 \\
\hline
\end{tabular}

$\mathrm{SE}=$ Standard error, $\mathrm{CD}=$ Critical difference, NS= Non-significant

Yield Parameters: The seed cotton yield was recorded (Table 9) in each plot after three pickings and has found that fertilizer application has increased the seed cotton yield significantly. It was maximum (2335.65 kg ha ${ }^{-1}$ ) in plot receiving recommended dose of fertilizer. This is significantly more as compared to other treatments. Lowest seed cotton yield (2023.15 kg ha $\mathrm{kg}^{-1}$ was obtained from plots receiving no fertilizer dose. The inoculation of Azospirillum + PSB + PPFM has brought about the insignificant increment in seed cotton yield and it was maximum ( $2289.35 \mathrm{~kg} \mathrm{ha}^{-1}$ ) in plot receiving inoculation of Surat strain of Azospirillum + PSB + PPFM, which was more as compared to other treatments and uninoculated control. The interaction effects due to fertilizer application and microbial inoculations were insignificant. The increases in yield of cotton obtained in the present exploration are full conformity with those reported in the past. Increases the yield of peal millet when inoculated with 
Azospirillum lipoferum [28, 34] and maize grain yield increases $31 \%$ with inoculation of PSB [17]. Similar results have been reported for various plants $[6,8$, $10,23,24,27,31]$.

Table 9: Effect of bioinoculants on fiber quality on irrigated cotton at different fertilizer level.

\begin{tabular}{|c|c|c|c|c|c|c|}
\hline Treatment & $\begin{array}{c}2.5 \% \\
\text { span } \\
\text { length } \\
(\mathrm{mm})\end{array}$ & $\begin{array}{l}\text { Uniformity } \\
\text { ratio }\end{array}$ & $\begin{array}{l}\text { Micronair } \\
\text { e value }\end{array}$ & $\begin{array}{l}\text { Tenacity } \\
\text { (g/t) } 3.2 \mathrm{~mm}\end{array}$ & EIG \% & SFI \\
\hline \multicolumn{7}{|l|}{ Main Plot } \\
\hline No N, P \& K at RDF & 25.68 & 52.25 & 4.81 & 17.05 & 5.31 & 10.12 \\
\hline $50 \% \mathrm{~N}, \mathrm{P} \& \mathrm{~K}$ at RDF & 25.56 & 51.25 & 4.71 & 17.09 & 5.25 & 10.75 \\
\hline $75 \% \mathrm{~N}, \mathrm{P} \& \mathrm{~K}$ at RDF & 25.21 & 51.16 & 4.70 & 17.69 & 5.39 & 11.47 \\
\hline $100 \% \mathrm{~N}, \mathrm{P} \& \mathrm{~K}$ at RDF & 25.72 & 52.08 & 4.71 & 16.92 & 5.33 & 10.18 \\
\hline SE & 0.20 & 0.28 & 0.06 & 0.26 & 0.11 & 0.31 \\
\hline$C D$ at $5 \%$ & NS & NS & NS & NS & NS & NS \\
\hline \multicolumn{7}{|l|}{ Sub plot } \\
\hline TNAU AZO + PSB + PPFB & 25.42 & 51.25 & 4.79 & 17.20 & 5.32 & 11.15 \\
\hline MAU AZO + PSB + PPFM & 25.43 & 51.16 & 4.66 & 17.40 & 5.31 & 11.14 \\
\hline Surat AZO + PSB + PPFM & 25.50 & 52.58 & 4.75 & 17.13 & 5.31 & 10.02 \\
\hline No inoculation & 25.83 & 51.75 & 4.74 & 17.01 & 5.34 & 10.22 \\
\hline SE & 0.16 & 0.53 & 0.07 & 0.25 & 0.65 & 0.43 \\
\hline CD at $5 \%$ & NS & NS & NS & NS & NS & NS \\
\hline \multicolumn{7}{|l|}{ Interaction (Fertilizer $\mathrm{x}$ inoculation) } \\
\hline $\begin{array}{l}\mathrm{SE} \\
\mathrm{CD} \text { at } 5 \%\end{array}$ & & 1.07 & & 0.51 & 013 & \\
\hline & NS & NS & NS & NS & NS & NS \\
\hline
\end{tabular}

$\mathrm{SE}=$ Standard error, $\mathrm{CD}=$ Critical difference, NS= Non-significant, EIG= Elongation percentage of cotton fiber, SFI= Short fiber index

The fiber quality of cotton as influenced by fertilizer application and inoculations of bioinoculants is assessed from each plot. The data are presented in Table 9. The data on different fiber quality parameters obviously evidenced that diverse treatments brought about the change in fiber quality of cotton. However, these changes could not achieve the level of significance. The span length of cotton fiber in different treatments ranged from 25.21 to $25.72 \mathrm{~mm}$, which is considered as medium type. The maximum span length $(25.21 \mathrm{~mm})$ was noted in the plot receiving Surat strain of Azospirillum + PPFM with $100 \% \mathrm{~N}, \mathrm{P}$ and $\mathrm{K}_{2} \mathrm{O}$ at recommended dose of fertilizer (RDF). Smallest span length $(25.21 \mathrm{~mm})$ was noted in the plot receiving $75 \% \mathrm{~N}, \mathrm{P}$ and $100 \%$ $\mathrm{K}_{2} \mathrm{O}$. With regards to inoculation effects, span length ranged between 25.42 to $25.83 \mathrm{~mm}$, which is considered medium type. In inoculation treatment maximum span length $(25.83 \mathrm{~mm})$ was observed in plot receiving no inoculation. Minimum span length was obtained in plots inoculated with TNAU strain of Azospirillum + PSB + PPFM. Maximum span length was reported in the plot receiving $100 \% \mathrm{~N}$ and $\mathrm{P}$ fertilizer while maximum tenacity and elongation percentage were recorded in the plot receiving $75 \%$ $\mathrm{N}$ and $\mathrm{P}$ fertilizers, which are classified as a good quality fiber on this account. The results obtained in the present investigation are in agreement with those reported in the past $[4,10,19,21]$.

The uniformity ratio of cotton fiber harvested from different treatments ranged from 51.16 to $52.25 \mathrm{~mm}$, which is being considered as excellent quality fiber. Greatest uniform ratio $(52.25 \mathrm{~mm})$ was recorded in the plot receiving no $\mathrm{N}, \mathrm{P}$ and $\mathrm{K}$, while least (51.16 $\mathrm{mm}$ ) was recorded in the plot receiving $75 \% \mathrm{~N}$ and $\mathrm{P}$ fertilizers. With regard to inoculation effects, the uniformity ratio ranged from 51.16 to $52.58 \mathrm{~mm}$, which is considered as excellent quality fiber. Highest uniformity ratio $(52.58 \mathrm{~mm})$ was obtained with the application of Surat strain of Azospirillum + PSB + PPFM. Minimum uniformity ratio $(51.16 \mathrm{~mm})$ was obtained in the plots inoculated with MAU strain of Azospirillum + PSB + PPFM. The micronaire value of cotton fiber ranged from 4.81 to 4.70 , which considered as average. The chief value is found in plot receiving no $\mathrm{N}$ and $\mathrm{P}$, while least value is found in plot receiving $75 \% \mathrm{~N}$ and $\mathrm{P}$. The tenacity of cotton fiber different treatments ranged from 16.92 to 17.69 $\mathrm{g} / \mathrm{t}$, which are low and falls in lowest grade. Amongst the treatments, tenacity of cotton fiber found largest (17.69 g/t) in the plot receiving $75 \% \mathrm{~N}$ and $\mathrm{P}$ fertilizers, while least tenacity $(16.92 \mathrm{~g} / \mathrm{t})$ is recorded 
in plot receiving $100 \% \mathrm{~N}$ and $\mathrm{P}$ fertilizers with regard to inoculation treatment. The tenacity of different treatments ranged from 17.01 to $17.40 \mathrm{~g} / \mathrm{t}$. Maximum tenacity $(17.40 \mathrm{~g} / \mathrm{t})$ was obtained with the inoculation of MAU strain of Azospirillum + PSB + PPFM and minimum with uninoculated control. Elongation percentage of cotton fiber (EIG \%) in different treatment found highest $(5.39 \%)$ was obtained with cotton lint harvested from the plot receiving $75 \% \mathrm{~N}$ and $\mathrm{P}$ fertilizers. With regards to inoculation effect, EIG \% differed from 5.31 to 5.34 percent. Maximum EIG\% (5.34 \%) was recorded with the uninoculated plots, while the lowest (5.31 \%) in plot receiving Sutat strain Aspirillum + PSB + PPFM. The short fiber index (SFI) in different treatments is found lowest $(10.12 \mathrm{~W})$ in plot getting no $\mathrm{N}$ and $\mathrm{P}$ fertilizer applied, while uppermost $(11.47 \mathrm{~W})$ in plot receiving $75 \% \mathrm{~N}$ and $P$ fertilizers. With regard to inoculation treatments, the SFI ranged from 10.02 to $11.15 \mathrm{~W}$. Minimum SFI $(10.02 \mathrm{~W})$ was achieved with the application of Surat strain of Azospirillum + PSB + PPFM, while maximum SFI (11.15 W) with the application of TNAU strain of Azospirillum + PSB + PPFM. Both the values are considered as good for cotton fiber. Results with regard to these quality parameters with microbial inoculation have been also reported in past $[4,10,25]$.

\section{CONCLUSIONS:}

Inoculation of Azospirillum, PSB and PPFMs along with chemical fertilizers resulted into the significant increase in shoot length of cotton. The interaction effect due to fertilizer and inoculation were substantial on all dates of observation Surat strain of Azospirillum was proved superior at all fertilizer levels. This investigation also indicated that inoculation of Azospirillum, PSB and PPFMs alongwith chemical fertilizers resulted into the considerable increase in fresh and dry shoot weight, root length, fresh and dry root weight, weight of boll and number of bolls in cotton.

The seed cotton yield of irrigated cotton was appreciably increased with the application of chemical fertilizers and inoculation of Azospirillum, PSB and PPFM. The superiority of Surat strain of Azospirillum + PSB + PPFM was evident at all the fertilizer levels and was immediately followed by MAU strain of Azospirillumn + PSB + PPFM. Inoculation of bioinoculants resulted into the improvement of fiber quality. Span length, Uniformity ratio, Tenacity and EIG percentage were increased with application of chemical fertilizers and bioinoculants, while micronaire value and SFI were minimum with the application of $\mathrm{N}$ and $\mathrm{P}$ fertilizers and inoculation of Azospirillum + PSB + PPFM, which are being considered as average type and good quality fiber respectively.

\section{ACKNOWLEDGEMENT:}

The authors wish to thanks Head, Department of Plant Pathology, Marathawada Agriculture University, Parbhani (M.S., India) for providing the necessary laboratory facilities.

\section{REFERENCES}

1. Ahmad, N. M. Rashid and A.G. Vaes, 1996. Fertilizer and their use in Pakistan NFDC Publication No. 4/96 Planning commission NFDC Islamabad Pakistan, pp: 142-175.

2. Alagwad, A.R. and A.C. Gaur, 1988, Associative effect of Thizobium and phosphate solubilizing bacteria on the yield and nutrient uptake of chickpea. PI. Soil, 105: 241-246.

3. Anonymous, 2002. Annual progress report of technology mission on cotton, minimission for the year 2002, pp: 206-219.

4. Cassman, K.G., T.A. Kerby, B.A. Robertsand, S.M. Brouder, 1990b. Reassessing potassium requirement of cotton for yield and fiber quality. Proc. of the 1990. Beltwide cotton production conference, pp: 60-64.

5. Dubey, S.K. 1997. Co-inoculation of phosphorus solubilizing bacteria with Brady Rhizobium Japonicum to increase phosphate availability to rainfed soyabean on vertisol. J. Indian Soc. Soil Sci., pp: 506-509.

6. Gitte, A.T., 2002. Effect of biofertilizers on growth and yield of rainfed cotton. M.Sc.(Agr.) Thesis, Marathwada Agricultural University, Parbhani, M.S., India.

7. Gunasekaran, S. and S. Shivkumar, 1996, Studies on nitrogen assimilatory enzymes of rice plants inoculated with Azospirillum strains. Indian J. Microbiol. 36(4): 223-225.

8. Gupta, N.S., K.T. Sadawarte, V.K. Mahoskar, B.J. Jadhav, and S.V. Dorak, 1999. Effect of graded levels of nitrogen and bioinoculants on growth and yield of marigold. J. Soil Crops, 9 (1): 80-83.

9. Hussain, T.T., J.F. Javaid, G. Parr, Jilani and M.A. Haq, 1999. Rice and wheat production in Pakistan with effective microorganism. Am. J. Alt. Agri., 14: 30-36.

10. Kadam, S.V., 2004. Effect of bioinoculents on yield and fiber quality of irrigated cotton. M.Sc.(Agr.) Thesis, Marathwada Agricultural University, Parbhani, M.S., India. 
11. Kalavati, B.P., P. Santhanakrishnan and M.P. Divyua, 2000. Effect of VAM Fungus and PSB in neem. Indian forester, 126(1):67-70.

12. Kavimandan, S.K. and A.C. Gaur, 1991. Effect of seed inoculation with Pseudomonas Spp. On phosphate uptake and yield of Maize. Curr. Sci., 40: 439-440.

13. Kulhare, P.S., S.K. Padihar and R.A. Khan, 1996. Effect of biofertilizers on soyabean under Taiwa command Area. Advances Agri. Res. India. 5:22-24.

14. Madhaiyan, M. S., M.Poonguzhali, S. Senthilkumar, Seshadri, H.Y. Chung and J.C. Yang, 2004. Growth promotion and induction of systemic resistance in rice cultivar Co-47 (Oryza sativa L.) by Methylobacterium spp. Botanical Bulletin of Academia. Sinica, 45: 315324.

15. Malligawad, L.H., K.G. Parameshwarappa and K. Giriraj, 2003. Studies on the effect of source phosphatic fertilizer and phosphorus solubilizing microorganisms on the yield attributes and yield of groundnut (Arachis hypogaea). ISOR National seminar: Stress management in oil seed, Jan. 28-30, 2003.

16. Mehandale, R.R., 1981. Occurrence, characterization and screening of dinitrogen fixing Azospirilla. M.Sc.(Agri.) Thesis, Mahatma Phule Agricultural University, Rahuri, M.S., India.

17. Mishra, O.R., V. S. Tomara, R.A. Sharma and A.M. Rajput, 1995. Response of Maize to chemical and biofertilizers. Crop Research Hossar, 1995.

18. Mukharjee, P.K. and R.K. Rani, 1999. Sensitivity of P uptake to change in root growth and soil volume as influenced by VAM, phosphate solubilizing bacteria in wheat and cheakpea. Ann. Agric. Res., 20(4): 528530.

19. Mullins, G.L., 1998. Cotton response to the rate and source of sulfur on a sandy coastal plain soil. J. Prod. Agric., USA. 11(2): 214-218.

20. Patil, R.A., 2001. Integrated nutrient management in cotton through bioinoculants. M.Sc.(Agr.) Thesis, Marathwada Agricultural University, Parbhani, M.S., India.

21. Phipps, B. J., W.E. Stevens, J.N. Ward and T.V. Scale, 1997b. The influence of the mepianat chloride (PIX) and nitrogen rate upon the maturity and fiber quality of upland cotton. Proc. of the Belt wide cotton production conference, New orleasns, LA, USA, 2: 1471-1472.

22. Rani, N.S. and S. Sathiamoorthy, 1991. Effect of organic biofertilizers on root enzyme activity nematode, total biomass and growth enhancement of papaya. South Indian Hort. 45(5-6):217-223.

23. Sharma, K.N. and K.N. Namdeo, 1999. Effect of biofertilizers and phosphorus on growth and yield of soybean. Crop Res. 17 (2): 160-163.

24. Sharma, R.A. and B.B. Parmar, 1997. Influence of biofertilizers and indigenous sources of nutrients uptake and productivity of rain fed soybean-gram cropping sequence. Crop. Res. 13 (1): 13-18.

25. Shaw, B.W., C.B. Parnell and R.E. Childeres, 1990. Effect of plant growth regulators on cotton fiber quality. Proc. of the 1990 Beltwide cotton production conference, pp: 101-106.

26. Singh and K. Kapoor, 1994. Solubilization of insoluble phosphate by bacteria isolated from different sources. Ecol. Environ., 12(1):51-55.

27. Sitaphale, D.V., 2003. Further study on integrated nutrient management in cotton. M.Sc. (Agri.) Thesis, Marathwada Agricultural University, Parbhani, M.S., India.

28. Smit, R.L., J.H. Bouton, S.C. Schank, K.H. Quesenberry, M.E. Tyler, 1976. N2 fixation in grasses inoculated with Spirillum lipoferum. Sci.193 (4257):1003-1005

29. Tien, T.M., M.H. Gaikins, and D.H. Hubbel, 1979, Plant growth substances produced by Azospirillum brasilense and their effect on growth of Pearl millet (Penisetum americanum). Appl. Environ. Microbial. 37(2): 1016-1024.

30. Vaishya, V.K., P.N. Bapat and V.M. Dubey, 1994. Phosphate solubilizing efficiency of micro-organisms on gram grown on vertisols. J. Ind. Soc. Soil Sci., 44(3): 524-526.

31. Vendan, R.T. and M. Subramanian, 1998. Phosphorus solubilizing and yield increase in rice due to bioinoculant. J. Ecobiol. 10(2): 233-237.

32. Wang, Chunling Yiling, C.L. Wang, and Y.T. Ling, 1997. Effect of different biofertilizers on the growth and flowering of Petuniax hybrida. Bull. Nattl-pigtung polytechnic Institute. 64: 251-261.

33. Wange, S.S. and D.B. Ranawade, 1997. Effect of microbial inoculants on fresh root development of grape var. Kishmis Charoni. Recent Hor. 4:27-31.

34. Wani, S.P., S. Chandrapalah, and P.J. Dart, 1985. Response of pearl millet cultivation. Expt. Agric.21:175-182. 